\title{
Production and Marketing Trends of Soy Bean in Ethiopia 2001-2017
}

\author{
Gebre-Egziabher Fentahun \\ Assosa University, Department of Agricultural Economics, P.O.Box 18, Assosa, Ethiopia
}

\begin{abstract}
This review investigates the status and trends of production and marketing of soy bean in Ethiopia. The high production record was obtained in 2015/16 production season, which is 81241.833 ton. But high yield (22 quintals per hectare) or (2.2 ton per hectare) was obtained during 2017 production season. Area covered by the crop from 2001/02 to 2016/17 production period shows uneven holding which moves up and down. This shows once the farmers produce the crop they ignore it coming year because of market problem of the crop. They even don't know how to locally process it. This leads them to carelessly engage in production of the crop. This needs attention of future intervention either by government or nongovernmental organizations on area of improving farmers' ability of processing soya bean, creation of favorable market condition for this crop. There is also high price fluctuation in the domestic market so it is very crucial to link commercially oriented small and large scale farmers to value chains. This means, industries engaged in processing of oil crops to produce edible oil need to be supported or encouraged to start processing soy bean. This needs a link with a group of soy bean producing farmers. Farmers need to be linked with soy bean processing factories as a result market is secured for farmers to become interested to engage in soy bean production. Promote soy production and processing among small holders, engaged in subsistence farming, for food security purposes.

DOI: $10.7176 / \mathrm{JMCR} / 59-02$
\end{abstract}

Publication date: August $31^{\text {st }} 2019$

\section{INTRODUCTION}

Soybean (Glycine $\max$ ) is a grain legume that is very nutritious and contains on average $40 \%$ protein. It is gaining ground internationally due to its multiuse use as human food, livestock feed, manufacturing purposes, and more recently, as a source of bio-energy (Myaka et al., 2005). Currently it also comes to be the world's most important source of vegetable oil. Unlike most other beans it contains $40 \%$ protein compared to $20 \%$ and $13 \%$ protein content in meat and egg, respectively $(\mathrm{FAO}, 2010))$. Moreover it contains $20 \%$ non-cholesterol oil and its fortified foodstuffs are considerably low-priced than other sources of high quality protein. It very well may be utilized directly for nourishment in the family unit or handled for soy milk, cooking oil and a scope of different items including newborn child weaning sustenance. Also the poultry sector industry uses soybean for feed production. Soybean grain often has a good market demand. The crop residues are also wealthy in protein and are great feed for domesticated animals form a good basis for compost manure. It is a source of edible oil (second most consumed oil in the world after palm oil) with the highest gross output of vegetable oil among the cultivated crops with total cultivated area of 117.7 million ha and total production of 308.4 million tons (FAOSTAT, 2015).

Food insecurity and malnutrition are among the urgent difficulties that creating nations confront nowadays. The significant staple food harvest of most creating Sub-Saharan African Nations, maize, contains low protein (5.2-13.7 \%) (FAO, 2010). The difficulties are particularly intense in Ethiopia and relatively more serious in the rural than urban areas, primarily due to low level of understanding of a balanced diet and absence of ability to buy animal source proteins.

Producing and consuming more soy would enhance the circumstance (Food Security) as soy gives a nutritious mix of both calorie and protein consumption: it is the most nutritionally rich crop product, as its dry seed contains the highest protein and oil content among grain legumes (topmost rich in protein) (40 to $42 \%$ protein) with a good sense of balance of the essential amino acids and has $18-20 \%$ oil on a dry seed weight basis (FAO, 2014). It is discounted and rich source of protein for poor farmers, who have less access to animal source protein, because of their low acquiring limit (low purchasing power). In this way, Soybean is an elective protein source to the rural families and can be utilized at home in different structures and the surplus can be sold to different buyers, producers and manufacturer for money (Urgessa T., 2014).

Many other products with a soya basis are also directly used for human consumption (soymilk, tasty soya, soy yogurt, snacks, soya sauce, protein extract and concentrates, etc.). In the major producing nations and especially in Brazil, Argentina, Paraguay and the USA soybean contributes fundamentally to the aggregate value added by the agricultural sector. In these nations, soybeans and its sub-products also occupy an important position in total export earnings. Among minor producers only India and Bolivia earn significant income from the exportation of soybean and derived products or by products (P. Thoenes., 2014).

In spite of the fact that it is a recent introduction in Ethiopia, records obtained for the period 2008 through 
2016 indicate that area, production and yield of soybean have become quick at a rate of $30.8 \%, 45.4 \%$ and $11.2 \%$ per annum respectively and reached 38,166 ha of land to produce 812,420 quintal of soybean with national average yield of $21.3 \mathrm{qt} / \mathrm{ha}$ (CSA, 2016). The present five-year plan, GTP II, has given due consideration for soybean production as industrial crop and its production is expected to increase from 0.72 million quintals in 2015 to 1.2 million quintals by the year 2020 to meet the demand of the market by making a linkage with the business industry and international market (GTP II, 2015).

Since it is all around adjusted to lowland to mid height agro-ecologies of the nation where the vast majority of the potential arable land is found achieving this target is likely essentially in the critical soybean developing parts of the nation including Western, South western, Southern and North-western parts of the nation. The entire low to mid altitude maize belt areas of the country are also appropriate for soybean production. In addition, Ethiopia's strategic location closer to the world's largest consumers of soybean and soybean products is also a feature which makes it great open door for the nation to target soybean as potential export commodity and import substitution (Birhanu et al., 2018).

Despite the importance of soy bean to address food insecurity problems prevailing in the country, little emphasis has been given to production, supply and export of this substantial commodity (Mekonnen H. and Kaleb K., 2014). This review is attempt to inspect the status and trends of production and marketing of soy bean with a purpose of generating information that help understand and evaluate the soy bean trade performance of the country that will enhance well-versed verdict(well informed decision) for taking measure and activities for extension of soy bean production and trade in Ethiopia.

\section{Objectives}

The overall objective of this review is to inspect the status and trends of production and marketing of soy bean in Ethiopia, and it specifically reviewed:

$>$ The current status and trends of soybean production and productivity in Ethiopia

$>$ Soybean marketing(Import and Export) trend

$>$ Price trend of Soybean in Ethiopia

$>$ Major Constraints of Soya bean Production in Ethiopia

\section{Methodology}

The design of this review is involved quantitative analysis of soybean production and marketing trend situation in Ethiopia. The data collected, interpreted and evaluated here obtained from secondary data sources (Mainly from Central Statistical Agency and FAOSTAT). Different research results have been used to assess the current situation, major constraints and marketing trend of soybean production in Ethiopia. Therefore, statistical analyses of raw data obtained from organizational sources were employed for the justification of the results (graph summary, simple average, table and so on)

\section{DISCUSSION}

\section{Soy bean Production, Productivity and area of Land}

There are good climatic and soil conditions for soybean production in South and Western Ethiopia which is indispensable both for commercial purposes in addition for subsistence farming (CDI, 2012). The issues (problems) of producing soybean is not only limited to market access in addition low profitability and production, lack of processing facilities, lack of capital to increase production and no market information system (no market data framework) for effective agricultural marketing (successful farming promoting) (Emana B., 2010).

The total area coverage under the production and whole volume of production of soy bean has been increasing over years. According to (Kaleb K., 2014), it is found, that the significant wellspring of increment in the total production of soy bean has been principally come about because of increment in area of land allocated for its production. The total hectare of land under soy bean production between 2001/02 and 2011/12 has increased by 10 folds and the total increment between 2001/02 and 2016/17 is greater than 20 folds, this is double as compared to the former one; while the total volume of soy bean production during $(2001 / 02-2016 / 17)$ has increased by more than 50 folds, this is far greater from the study of (Kaleb K., 2014) total increment between 2001/02 and 2011/12 equals to 21 fold. The increased hectare of land for the production of soy bean as well as increased total production during the last 15 years has been resulted from increasing demand for soy bean at local and international market (CSA 2001-2017). 
Table 1 Soy bean Production and area coverage in Ethiopia (20001/02-2016/17)

\begin{tabular}{|l|l|l|l|l|}
\hline Production Year & $\begin{array}{l}\text { Area coverage } \\
\text { (Hectare) }\end{array}$ & Total Production (Ton) & \multicolumn{1}{|c|}{$\begin{array}{c}\text { Productivity } \\
\text { (Ton/ha) }\end{array}$} & $\begin{array}{c}\text { Yield } \\
\text { (Quintal/ha) }\end{array}$ \\
\hline $2001 / 02$ & 1,769 & 1620.5 & 0.92 & 9.2 \\
\hline $2003 / 04$ & 1,027 & 457.4 & 0.45 & 4.5 \\
\hline $2004 / 05$ & 2,606 & 833.5 & 0.32 & 3.2 \\
\hline $2005 / 06$ & $3,326.52$ & 3811.89 & 1.15 & 11.5 \\
\hline $2006 / 07$ & $6,352.46$ & 5848.95 & 0.92 & 9.2 \\
\hline $2007 / 08$ & $7,807.40$ & 8400.64 & 1.08 & 10.8 \\
\hline $2008 / 09$ & 6236.04 & 7898.9 & 1.27 & 12.7 \\
\hline $2009 / 10$ & $5,678.69$ & 15824.42 & 1.27 & 12.7 \\
\hline $2010 / 11$ & 11261 & 35880.29 & 1.41 & 14.1 \\
\hline $2011 / 12$ & 19397 & $636,53.101$ & 1.85 & 18.5 \\
\hline $2012 / 13$ & $31,854.75$ & 61024.916 & 1.99 & 19.9 \\
\hline $2013 / 14$ & $30,517.38$ & 72183.745 & 1.99 & 19.9 \\
\hline $2014 / 15$ & $35,259.76$ & 81241.833 & 2.05 & 20.5 \\
\hline $2015 / 16$ & $38,166.04$ & 81234.659 & 2.13 & 21.3 \\
\hline $2016 / 17$ & 36635.79 & 2.22 & 22.2 \\
\hline
\end{tabular}

Source: Central Statistical Agency of Ethiopia (2001-2017)

Despite the tremendous increment in the measure of land assigned for soy bean production during the last 15 years, the amount of land allotted for the production of soy bean is very low compared to land allocated for other oil crop commodities (FAO 2010). Productivity (efficiency gains) gains are very instrumental for sustainable agricultural growth in general stipulated in the national agricultural advancement strategy of the country.

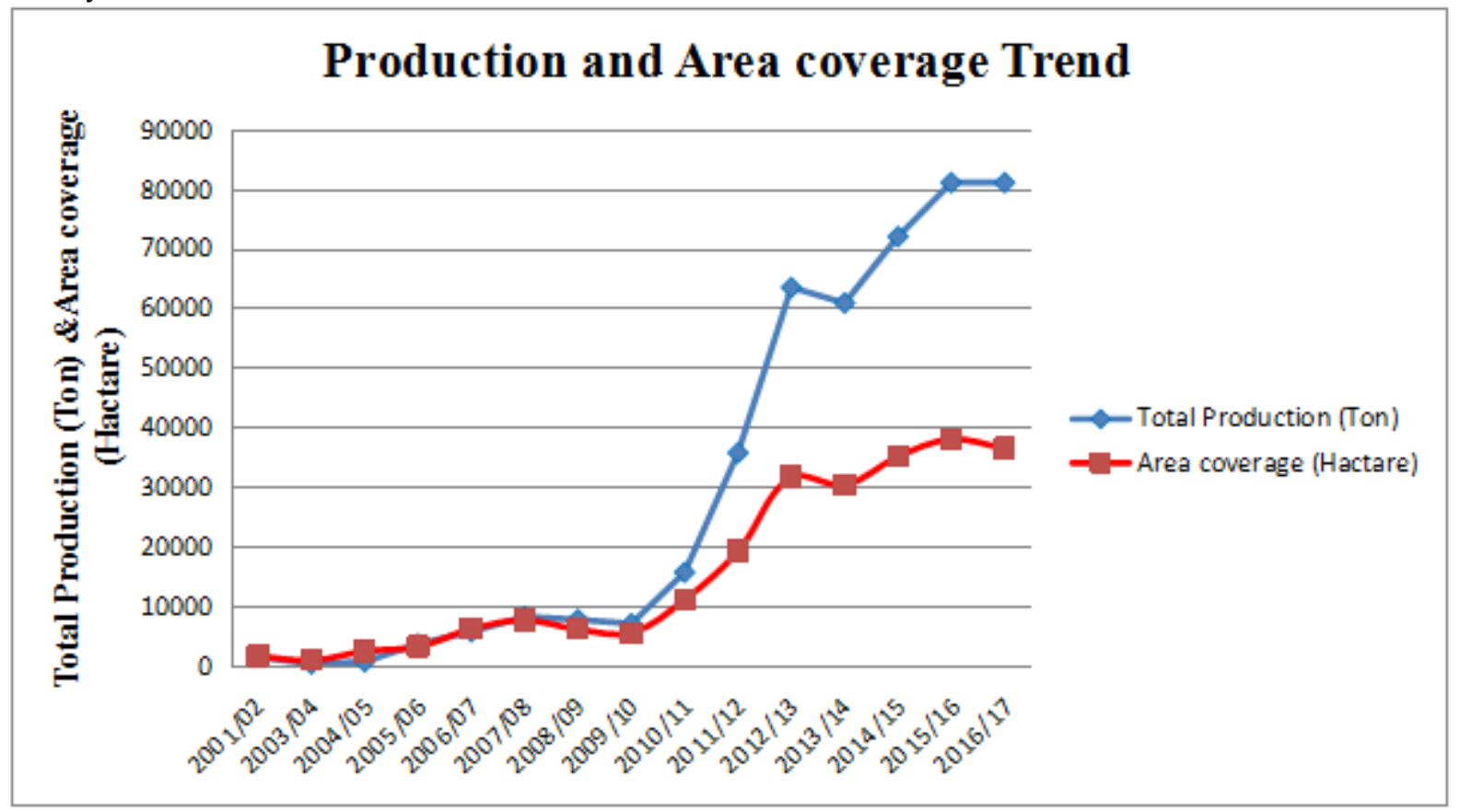

Figure 1 Production and Area coverage Trend (Source: Based on data obtained from CSA)

Productivity level of many other major crops is very low. The current normal national productivity level of soy bean is additionally low. The average productivity level of soy bean during the last 15 year was 1.4 ton/ha. This level is additionally low contrasted with the potential which could go up to 4 ton/ha if improved varieties are used. The last 15 years trend in the productivity level has grown from 0.92 ton/ha in 2001/02 to 2.22 ton/ha in 2016/17 (Table 1). During this period average productivity level has been greater than doubled. 


\section{Productivity trend (Ton per Hectare or Quintal per Hectare)}

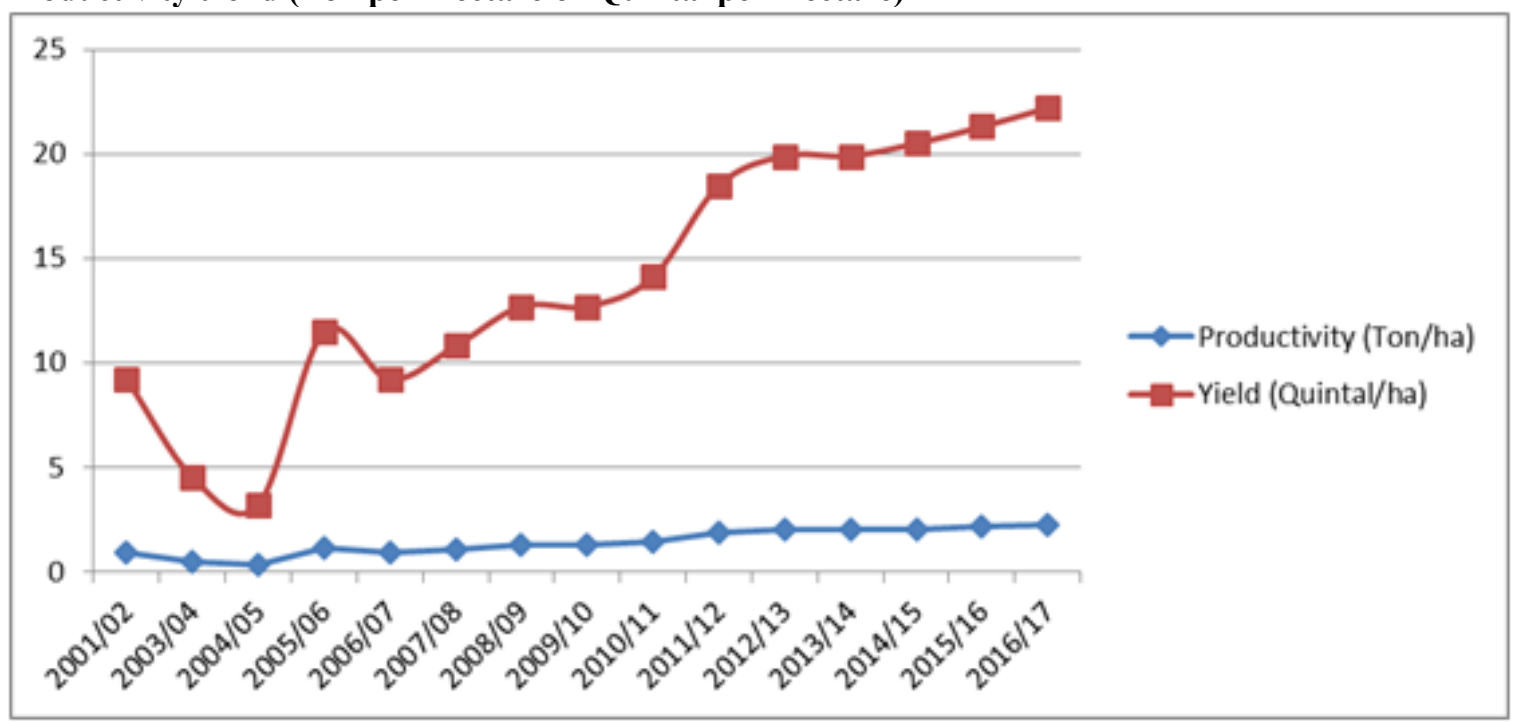

Figure 2 Soybean Productivity or Yield (Source: Based on data obtained from CSA)

\section{Export and Import volume of soybean in Ethiopia}

As an agrarian economy it is little to anticipate that for one country will import more agricultural products than it exports. However, the consistently expanding aggregate exchange shortage/trade deficit/ in Ethiopia originates from both agricultural and industrial sector. The country had recorded a tremendous exchange volume shortage/trade deficit/ in some major agricultural product where it has potential to narrow the ever increasing aggregate trade deficit. The country had recorded a huge trade volume deficit in some major agricultural products like soya bean (Gebeyehu, 2015). This huge difference could also be reflected through the value measure or volume measures. Let us see the volume difference between import and export in Ethiopia:

Table 2 Import and export of soybean $(\mathrm{Kg})$ in Ethiopia

\begin{tabular}{|l||l|l|l|}
\hline \hline \multicolumn{1}{|c|}{ Year } & Import & \multicolumn{1}{|c|}{ Export } & \multicolumn{1}{|c|}{ Volume Difference } \\
\hline 2002 & 2 & 181,667 & 781,667 \\
\hline 2003 & 597078 & 70568 & $1,042,832$ \\
\hline 2004 & 2953147 & 0 & $-2,953,147$ \\
\hline 2005 & 7523366 & 5880 & $-7,517,486$ \\
\hline 2006 & 117661 & $2,195,905$ & $2,078,244$ \\
\hline 2007 & 573904 & $2,120,907$ & $1,547,003$ \\
\hline 2008 & 6569770 & 462,010 & $-6,107,760$ \\
\hline 2009 & 512495 & 357,284 & $-155,211$ \\
\hline 2010 & 1405646 & $1,004,496$ & $-401,150$ \\
\hline 2011 & 363567 & $4,221,000$ & $3,857,433$ \\
\hline $2012 / 13$ &
\end{tabular}

\section{Source: CSA (Central Statistical Agency)}

Export of Soy bean in Ethiopia has been started in 2004 and there was no well record of export (even if there is data in somehow it seems unrealistic) of any soy bean or soy bean products before 2004. Ethiopia is exporting only soy bean grain and there is no other processed products of soy bean are started to be exported. The last ten years trend in the volume of exported grain of soy bean has been expanding. At the year 2008 the highest volume of export has been registered and has immediately declined in a significant amount. The average volume of annual soy bean export is 1.4 million $\mathrm{Kg}$. This export volume is very far from the volume of imported soy bean products. The trade deficit which is the difference between imported and exported volume of soy bean is about 138 million $\mathrm{Kg}$ on average. This shows that there is a huge demand in the domestic market for soy bean products and give warranty for local investors to engage in soy bean production. 


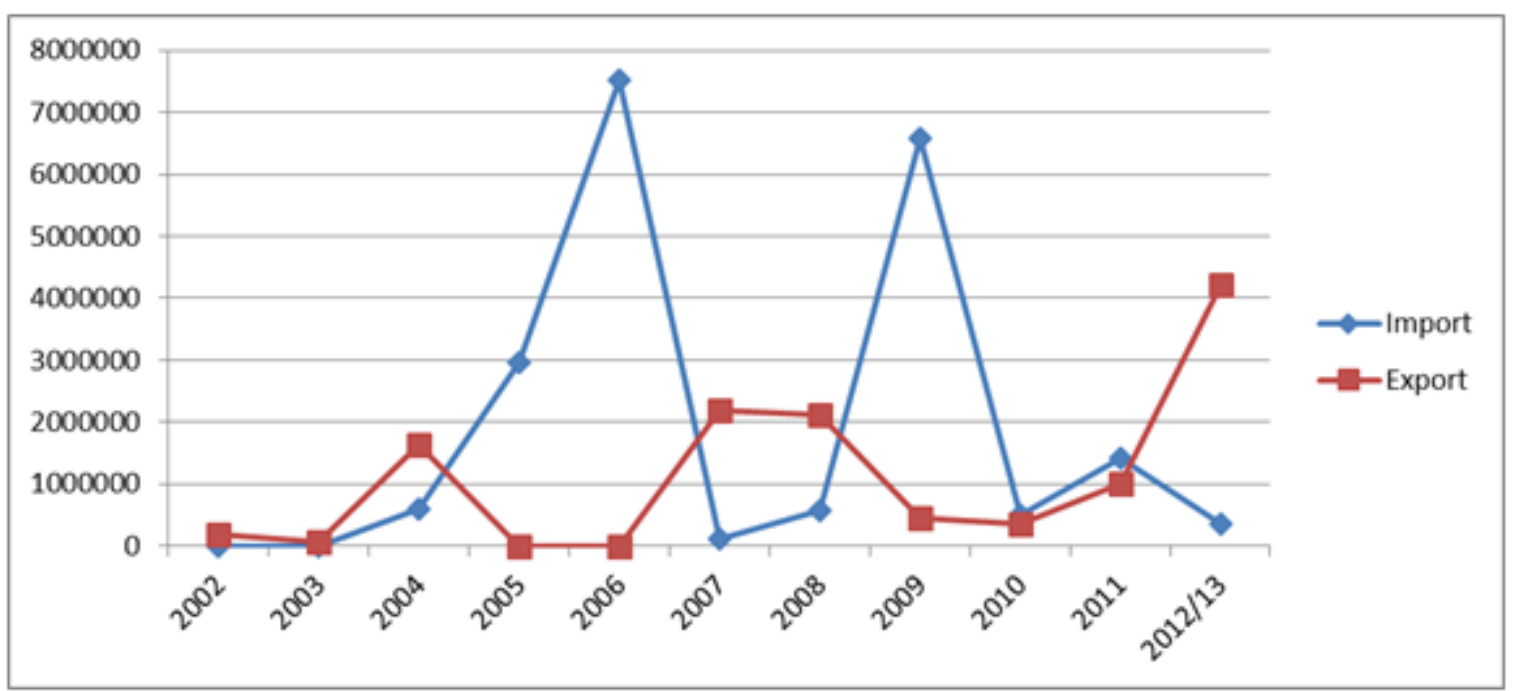

Figure 4 Trend in total volume of soy bean grain export and import

\section{Price Trends of Soybean}

In 2012 the domestic price has gone down in October there was a huge gap between domestic and international price but now the gap has closed. Processors are happy with prevailing price but producers are discouraged; partly because of the high expectation following the unusual historic price. Some producers noted high price variation across geographic areas as bigger concern over the decreasing trend; in areas where there is a better infrastructure and market information prices are high and stable but in the remote ones such as Metekel the reverse is true (Mekonnen H. and Kaleb K., 2014).

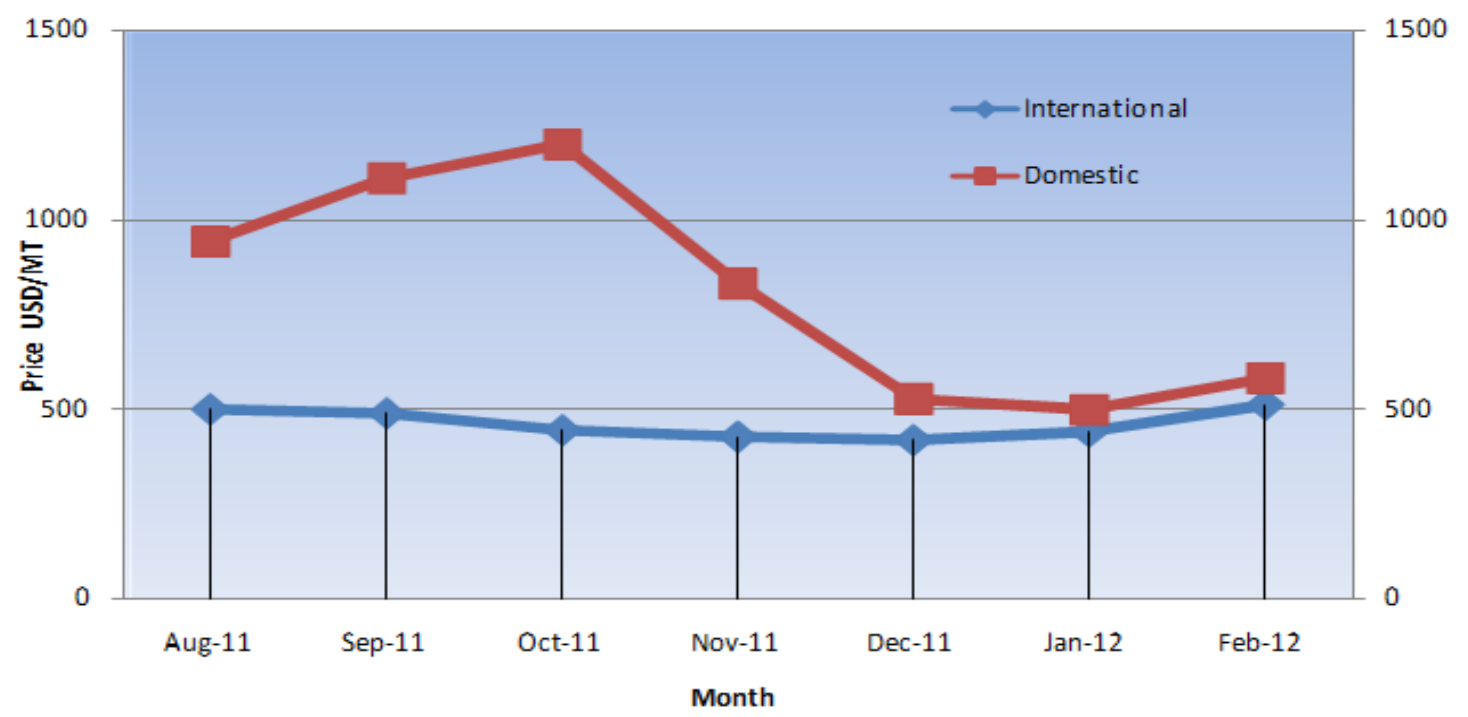

Figure 5 Price Trend for Soybean for International and Domestic Market

(Source: Mekonnen H. and Kaleb K., 2014)

This result highly tone/concise with the recent study by (Birhanu et al., 2018): Soybean producer farmers sold majority of the produce ( $88 \%$ ) within the first six months after harvest (December to May). The price of soybean was also observed to be low immediately after harvest and high in the last three months (August to October) of the production season.

\section{Major constraints of soybean production}

Although soybean breeding and production have been going on in Ethiopia since the 1950's, it was not easy to achieve wider dissemination and production of the crop. The main limitations were lack of know-how of the local farmers on the utilization aspect of the crop, unavailability of attractive market for the produce, and lack of systematic approach in popularizing the crop, which emphasized training farmers on the production of soybean, its utilization, and market potential. Consequently, the land allotted for growing soybean in the country was limited for several years. The following are also major problems that are attributable to low level of soy bean 
production in the country.

$>$ Weak market linkage between producers, processors, exporters and consumers

$>$ Limited use of improved varieties: Though, increased productivity cannot be associated with purely to research, the contribution of research outputs in terms of improved varieties and associated agronomic practices takes the lion share of improvement. The trend in yield for major cereals show considerable increase in the last ten years which is highly associated with the use of seeds of improved crop varieties, application of fertilizer and better extension services.

$>$ Limited knowledge in use of soy bean in cropping system

\section{CONCLUSION AND RECOMMENDATION}

This review investigates the status and trends of production and marketing of soy bean in Ethiopia. The high production record was obtained in 2015/16 production season, which is 81241.833 ton. But high yield (22 quintals per hectare) or (2.2 ton per hectare) was obtained during 2017 production season. Area covered by the crop from 2001/02 to 2016/17 production period shows uneven holding which moves up and down. This shows once the farmers produce the crop they ignore it coming year because of market problem of the crop. They even don't know how to locally process it. This leads them to carelessly engage in production of the crop. This needs attention of future intervention either by government or nongovernmental organizations on area of improving farmers' ability of processing soya bean, creation of favorable market condition for this crop.

There is also high price fluctuation in the domestic market so it is very crucial to link commercially oriented small and large scale farmers to value chains. This means, industries engaged in processing of oil crops to produce edible oil need to be supported or encouraged to start processing soy bean. This needs a link with a group of soy bean producing farmers. Farmers need to be linked with soy bean processing factories as a result market is secured for farmers to become interested to engage in soy bean production. Promote soy production and processing among small holders, engaged in subsistence farming, for food security purposes.

\section{REFERENCE}

Birhanu , Yalew M., and Adam B. (2018) ."Analysis of Cost and Return of Soybean Production under Small holder Farmers in Pawe District, North Western Ethiopia at Ethiopian Institute of Agricultural Research".

CSA (Central Statistical Agency of Federal Democratic Republic of Ethiopia), 2001-2017. Annual report.

Ethiopian ATA \& USAID Investment Support Program (2013). "Immediate opportunity to invest in soybean meal processing for Ethiopia's booming livestock and poultry sectors".

FAO (2010). Food outlook. Oil Seeds Business Opportunities Ethiopia, 2009; J.H.M. Wijnands, J. Biersteker, E.N. van Loo.

FAOSTAT (2015). Food and Agriculture Organization of the United Nations Statistical Database available at http://www.fao.org/faostat.

Gebeyehu AB., (2015). "Major Agricultural Trade Volume in Ethiopia". Trade Balance and Exchange Rate Relations a Structural Break Analysis

Greenberg, P and Hartung, H.N. (1998). The whole soy cookbook: 175 delicious, nutritious, easy to prepare recipes featuring tofu, tempeh, and various forms of nature's healthiest bean. Three Rivers Press, New York.

GTP II (Growth and Transformation Plan II) (2015). Ministry of Agriculture and Rural Development Second Growth and Transformation plan, Addis Ababa, Ethiopia.

Myaka, F. A., Kirenga, G., Malema, B. (Eds) (2005). Proceeding of the First National Soybean Stakeholders Workshop, 10 - 11 November 2005, Morogoro, Tanzania.

Osho, S.M. (1995). "Soybean processing and utilization research at International Institute of Tropical Agriculture”. Processing from SOYAFRICA'95: Johannesburg, South Africa, 4-5 October 1995.

P. Thoenes, "Soybean International Commodity Profile, Markets and Trade Division Food and Agriculture Organization of the United Nations", (2014), pp. 1-25.

Mekonnen H. and Kaleb K. (2014). "Trends in Soy Bean Trade in Ethiopia at Ethiopian Institute of Agricultural Research".

Urgessa T. (2014). "Empirical Review of Production, Productivity and Marketability of Soya Bean in Ethiopia" at Oromia Agricultural Research Institute 